\section{Education and inclusive growth in West Africa}

Inclusive growth in West Africa

\author{
Oluwatosin Adeniyi, Patricia Iyore Ajayi and \\ Abdulfatai Adekunle Adedeji \\ Department of Economics, University of Ibadan, Ibadan, Nigeria
}

\begin{abstract}
Purpose - Many West African countries face the challenge of growth inclusiveness. The region is also facing challenges of equipping its teeming population with high-quality skills despite many reforms and initiatives introduced in the past. This study, thus, identifies education as a crucial contributory factor to growth inclusiveness in the region. It, therefore, examined the role of education in growth inclusiveness in West Africa between 1990 and 2017.

Design/methodology/approach - The study utilised different proxies to capture quantity and quality dimensions of education. The unit root and ARDL "Bounds" tests were employed at a preliminary stage. Based on the preliminary tests, the study explored autoregressive distributed lags modelling technique to capture the short-run and long-run dynamic effects.

Findings - The empirical results reveal a positive impact of school enrolment measures in most of the countries in both short-run and long-run. Education quality measure exerts positive impact and significant in few countries under consideration.

Practical implications - These countries should give adequate attention to quality when designing education policy to foster their inclusive growth.

Originality/value - This study highlights the critical role of education in the inclusive growth pursuit. Education quantity is important to growth inclusiveness but the quality of education is more fundamental. The quality of education possessed determine to a large extent, what individual can contribute to the productive activities within the economy and accessibility to benefits from economic prosperity.
\end{abstract}

Keywords West Africa, Education, ARDL, Inclusive growth

Paper type Research paper

\section{Introduction}

The record of growth in developing countries specifically in the last 20 years has been impressive especially in countries from sub-Saharan Africa (SSA). This is evident in the delivery of consistent positive growth digits from the average annual growth of $1.6-4.5 \%$ over the last two decades (see WDI, 2016). This pattern can similarly be observed in West African countries as they have recorded an average annual growth of $4.9 \%$ in the last two decades. As a matter of fact, some of the countries that recorded impressive and consistent positive annual growth in the region include Nigeria, Ghana, Senegal and Burkina Faso. These countries have demonstrated remarkable performance in maintaining high growth rates relative to other developing economies.

One of the key objectives of these countries is sustenance of consistent growth over the years, though there was negative growth in some economies such as Nigeria, when there was a significant drop in the international oil price in 2015. This, for instance, resulted in a

\section{JEL Classification - A2, I12, O4}

(C) Oluwatosin Adeniyi, Patricia Iyore Ajayi and Abdulfatai Adekunle Adedeji. Published in Journal of Economics and Development. Published by Emerald Publishing Limited. This article is published under the Creative Commons Attribution (CC BY 4.0) license. Anyone may reproduce, distribute, translate and create derivative works of this article (for both commercial and non-commercial purposes), subject to full attribution to the original publication and authors. The full terms of this license may be seen at http://creativecommons.org/licences/by/4.0/legalcode
Received 13 May 2020 Revised 22 July 2020 Accepted 5 August 2020

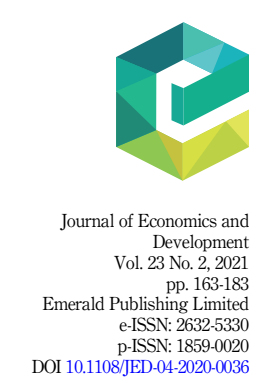


JED

23,2

164

significant drop in the growth as well as a recession in a country such as Nigeria. This, further raises the question of whether these countries can continue to base their growth on commodity prices. In the recent years, attention has been shifted to inclusive growth since most developing countries especially West African countries, that demonstrate high economic growth trajectory, are still faced with enormous socio-economic problems. According to Ianchovichina and Gable (2012), inclusive growth guarantees sustainable and rapid decline in poverty and inequality through labour force contribution as well as benefiting from economic growth process. In addition, growth inclusiveness ensures income expansion of lower-income group at fast pace while no social groups are not neglected in the growth process (Warner, 2012). This narrative could not be found in many West African countries.

The essence of inclusive growth has been documented in the literature (see Oyinlola et al., 2020; Raheem et al., 2018; World Economic Forum, 2014; OECD, 2013; Arezki and Nabil, 2012). Thus, the challenge facing the developing region such as West Africa can be linked to the lack of inclusiveness of the economic growth trajectory. One key candidate that drives this growth inclusiveness is the accumulation of skills and knowledge through education. Many developed countries built their growth on their human capacity advancement particularly through the provision of quality education to their citizens. Thus, their growth created many opportunities that allowed people to contribute enormously to growth processes as well as increase economic prosperity accruing to the citizenry. On this basis, West African countries need to re-strategize by creating knowledge-based economies rather than commodity-based economies. This is necessary in order to ensure that a greater number of citizens contribute actively in growth process.

Further, as argued in the literature, knowledge accumulation has been identified as a key driver of growth because it involves building human capacity to raise the level of productivity (Kotaskova et al., 2018; Novak and Dahal, 2016; Jalil and Idrees, 2013). Undoubtedly, West African countries have been making some progress in some areas of human capital development. This is apparent in the success recorded in school enrolment. In recent time, the region recorded a high number of school enrolment (i.e. primary and secondary). This coincides with an episode of high growth rate in the region which give insight to the level of human capital investment in the region. Accessibility of a larger number of the population to education gives the opportunity to the citizens to participate in the growth process through their engagement in productive activities. By this, people are expected to have access to many opportunities thereby expanding the prosperity of the region. Despite the progress recorded in educational quantity (i.e. school enrolment), there is still serious issue with education quality which inclusive growth heavily relied on. This further reflects in the persistent socio-economic problems affecting the region. The challenge here lies in the insufficiency of the indicators to assess the progress of these countries in terms of education quality. For instance, the increase in school enrolment may be necessary but may not translate to acquiring the skills needed to contribute meaningfully to the growth process. Similarly, Hanushek and Wößmann (2007) argue that educational quality matters in the growth process rather than mere school enrolment. This implies that an assessment of the role of education in growth inclusiveness needs to go beyond quantity but also quality.

The tenuous pattern of economic prosperity in these countries specifically, has continued to raise questions on how this high growth trajectory appears not to have created opportunities for a greater number of the citizenry. Indisputably, these countries are still struggling in recording outstanding performance in multiple indices of measuring economic development. They are ranked amongst the lowest performers in some key indicators such as school completion rate, maternal mortality, teacher-pupil ratio, control of corruption, infant mortality adult and literacy rate amongst others. Despite the performance in economic 
growth, there is still a high level of unemployment amongst the youths, high poverty rate, high out-of-school children, high inequality amongst others in the region. According World Economic Forum report (2014), education, and skills and employment were identified as critical to building growth inclusiveness and development. Thus, there is more to do in West African countries in terms of equipping the teeming population with quality education for them to participate in the growth process significantly.

Existing studies on economic growth in West African countries (such as Adedeji and Oyinlola, 2019; Ayinde and Yinusa, 2016; Sacerdoti et al., 1998 amongst others) have focussed more on other determinants (financial development, human capital amongst others) while little attention has been given to nature of education (in terms of quality and quality) and inclusive growth. Thus, this study posits that West African economies should be more concerned about the inclusiveness of their growth through the quality of education. Relying on performance in school enrolment is not sufficient and this is evident in the high level of unemployment due to scarce opportunities. Despite the impressive number of studies in the area of growth in sub-Saharan Africa including West African countries in particular, the role of education in growth inclusiveness of West African countries have been given little attention in the literature. Therefore, this study seeks to explicate the influence of education on growth inclusiveness. In addition, the study considers different measures of education to capture both its quantity and quality dimensions. Thus, this study hypothesizes that growth is not sufficient to measure the progress in the economy but rather the inclusiveness of growth is more important. This inclusiveness can only be achieved when people have quality education to contribute meaningfully to productivity level. This study captures the quality of education through a proxy that measures the rate of return to education and average years of schooling (i.e. index of human capital) while quantity is captured through the traditional measure (i.e. school enrolment). Therefore, the study provides a detailed analysis and evaluation from the empirical approach, on the growth inclusiveness process in West Africa through education. Specifically, we seek to provide answers to the following research questions: does education promote growth inclusiveness in the West Africa? What nature of education enhances growth inclusiveness in the region? Does the nature of education that impact growth inclusiveness varies across countries in the region?

The study conducts a country-by-country analysis for eight countries in West Africa between 1990 and 2017. The autoregressive distributed lag (ARDL) modelling technique is deployed to capture the short-run and long-run impacts. The rest of the paper is structured as follows: The second section captures the synopsis of the related literature. The third section focusses on the methodology and model specification. The fourth section presents the results and discussion, while the last section deals with conclusion and some policy lessons.

\section{Synopsis of related studies}

In recent years, multilateral corporations, national governments and regional blocs have been intensifying effort towards achieving inclusive growth since high economic growth is not sufficient to addressing several socio-economic problems in the developing countries. This is premise on the high unemployment rate, huge income disparity, ever-increasing poverty rate amongst others, in the developing region. According to Raheem et al. (2018), inclusive growth is a growth that ensures all income, social and economic groups contribute to the expansion of productivity or growth process. Similarly, growth is inclusive when there is increase in social opportunity function which relies on average opportunities available to the citizenry and distribution of opportunities amongst different citizenry (Ali and Son, 2007). Therefore, the economic growth that solves the socio-economic problems can be regarded as inclusive growth. But, inclusive growth also relies significantly on sustainability and continuity (i.e. must be steady and stable over time). This idea of growth has been championed by Organization for

\section{Inclusive growth in West Africa}


JED

23,2

166

Economic Cooperation and Development (OECD), United Nations Development Programme, World Bank amongst others. Several plausible determinants have been identified for inclusive growth and human capital is one of the key drivers of such growth.

Human capital is seen as one of the drivers of economic growth. Education and health are the components of human capital needed for economic growth. Several works in the literature have established the relationship between education and economic growth. These studies include Nowak and Dahal (2016), Gyimah-Brempong (2006), Kotásková et al. (2018), Barro (2013), Jalil and Idrees (2013), Lin (2003), amongst others. Gyimah-Brempong et al. (2006) investigated the impact of higher education on economic growth in 34 African countries over the 1960-2000 period using dynamic panel data estimator. They reveal that there is a positive and statistically significant relationship between all levels of education and economic growth. Similarly, Jalil and Idrees (2013), found a positive effect of different levels of education on economic growth in Pakistan.

Some studies argued that not all the levels of education have a significant impact on economic growth. Tertiary education is construed to be more significant to economic growth. However, the role of primary and secondary education should not be undermined as they provide the foundation upon which tertiary education is built. In a study conducted by Nowak and Dahal (2016) on the contribution of education on economic growth in Nepal, using ordinary least square (OLS), a positive relationship was found between education and economic growth. They further established that tertiary education is most significant to growth while elementary education is less significant. The expertise and skill taught by tertiary education institutions are the reason why it contributed to growth than the primary and secondary school education. Individuals with primary education are still not considered to be sufficiently equip with the skills needed for higher productivity in the economy. One of the channels through which education contributes to growth is research and development (R\&D). In the European countries, the significant source of growth is the R\&D of higher educational institutions to technological capital (Pastor et al., 2018). A well-educated labour force increases the total factor productivity and contribute to factor accumulation (Babatunde and Adefabi, 2005). Barro (2013) argued that the average years of schooling attainment is positively related to the level of growth. Delgado et al. (2013) showed the importance of education for economic growth. Wolfenden (2015) provides a detail overview of education challenges in Africa where quality at secondary and tertiary levels are greatly affected. This, in turn, retards growth process as a larger share of the population does not possess adequate knowledge and skills.

Recently, focus has been shifted towards inclusive growth due to the fact that some countries with high growth rate are still characterised by high poverty level and unemployment rate. More importantly, the relevance of inclusive growth has been demonstrated on a global, regional and national levels (Raheem et al., 2018). Studies have conducted in this regard which include Saad-Filho (2010), Lin (2012), Raheem et al. (2018), Oyinlola and Adedeji (2019), Adedeji and Adeniyi (2019), amongst others. For instance, Adedeji and Adeniyi (2019) reveal that primary school enrolment significantly influenced inclusive growth for all countries in Economic Community of West African States (ECOWAS) region except Burkina Faso. Similarly, Oyinlola and Adedeji (2019) show that human capital positively influences inclusive growth in SSA region. In addition, education expenditure plays significant role in the growth inclusiveness in SSA region (Raheem et al., 2018). Employing dataset for 38 developing countries, structural transformation was found to be growth-enhancing for Asian countries while it is growth-reducing for Africa (Lin, 2012). In measuring the impact of education using educational factors in this study, attention is given to the difference between quantity and quality measures of education. Eventually, what matter is how education is able to impact economic growth and this relies on the quality of education received by the population. 


\section{Methodology}

\subsection{Model specification}

Quality education creates an avenue for an individual to participate in the growth process as well as benefitting from economic prosperity. Interestingly, the West Africa region has recorded progress in the total primary and secondary school enrolment rates in recent time. In addition, the region has also benefitted from a high and stable growth rate in the last two decades except for the recent burst in the oil market in late 2014. Despite recording high and stable growth coupled with improvement in school enrolment rate, there is a high level of unemployment, poverty and inequality. This has been aptly captured by analysts as "joblessness growth". Theoretically, education is expected to equip individuals with skills to engage in the production process. The quality of education thus determines the extent to which individuals can contribute to productivity and thereby share in economic prosperity. This study relied on the augmented neoclassical model proposed by Barro (2013) and Mankiw et al. (1992). Thus, we examine the direct effect of education on inclusive growth. In addition, we investigated if the choice of education measure used for analysis (quality and quantity) matter for growth inclusiveness. Given this, we specify the baseline inclusive growth equation as follows

$$
Y_{t}=\alpha_{0}+\alpha_{1} \mathrm{CAP}_{t}+\alpha_{2} \mathrm{LABF}_{t}+\alpha_{3} E_{t}+\alpha_{4} X_{t}+\varepsilon_{t}
$$

From Eqn 1, $Y$ represents the log of GDP per person employed which serves as a proxy for inclusive growth. There is no consensus on the measurement or definition of inclusive growth in the literature. However, the justification for our measure is due to the fact it captures the income per worker. In other words, the measure focusses on people who engaged in the production process. It also captures the average opportunities available to the population and how these opportunities are shared amongst the population (Ali and Son, 2007). This measure amply captures growth and its sustainability as it encompasses unemployment level, income inequality and poverty level in a country (See Raheem et al., 2018 and Oyinlola and Adedeji, 2019). Thus, the GDP per person employed is appropriate in the context of our study as the proportion of the population that benefits from economic prosperity or opportunity is captured.

In a standard growth model, labour and capital are critical in the production process, therefore both variables are included in our model. LABF is measured by labour force participation rate as a percentage of total population (ages 15-64 years) and $C A P$ is the capital stock as a percentage of GDP. $E_{t}$ is the log of education indicators measured in terms of quantity (proxy by primary and secondary school enrolments - PSE and SSE, respectively), and quality (proxy by the index of human capital - IHC). These indicators provide robust information about seeking knowledge and quality of knowledge (Hanushek and Wößmann, 2007; Barro and Lee, 2013; Beck and Hall, 2013). It is important that individuals seek for knowledge which will influence productivity partially. However, the quality of knowledge is very critical for growth inclusiveness. The choice of proxy for quality is hinged on its computation which requires average years of schooling and an assumed rate of return to education (see Psacharopoulos, 1994; Barro and Lee, 2013; and Cohen and Leker, 2014). $X_{t}$ captures the control variables in the model. Theoretically, there are other key control variables that are preconditions for growth to be inclusive. These include foreign direct investment as a percentage of GDP (FDI) [1], inflation rate (INF) [2] and government consumption as a percentage of GDP (GOVT) [3]. The following variables are sourced from World Development Indicators (2018): GDP per person employed (constant 2011 PPP \$), foreign direct investment, net inflows ( $\%$ of GDP), labour force participation rate, total ( $\%$ of total population ages 15-64), primary school enrolment (as percentage of gross), Secondary school enrolment (as percentage of gross), inflation, GDP deflator (annual \%) and government
Inclusive growth in West Africa 
JED

23,2

168

final consumption expenditure (as percentage of GDP) while Capita stock (US million dollars) and Index of Human Capital are sourced from Penn World Table Version 9.

\subsection{Estimation techniques}

The use of ARDL is hinged on the pattern of integration from the unit root test as well as the outcome of the cointegration test. Thus, the study utilised the augmented Dickey-Fuller (ADF) and Philip Perron unit root tests and ARDL "Bounds" cointegration test. The preliminary tests are preconditions for the ARDL approach.

Following Pesaran et al. (2001), Eqn (1) can be expressed in the UECM form of the ARDL model as follows:

$$
\begin{aligned}
D(Y)_{t} & =\alpha_{0}+\sum_{i=1}^{m 1} \alpha_{1 i} D(Y)_{t-1}+\sum_{i=0}^{m 2} \alpha_{2} D(\mathrm{CAP})_{t-i}+\sum_{i=0}^{m 3} \alpha_{3} D(\mathrm{LABF})_{t-i}+\sum_{i=0}^{m 4} \alpha_{4} D(E)_{t-i} \\
& +\sum_{i=0}^{m 5} \alpha_{5} D(X)_{t-i}+\lambda_{1}(\mathrm{CAP})_{t-1}+\lambda_{2}(\mathrm{LABF})_{t-1}+\lambda_{3}(E)_{t-1}+\lambda_{4}(X)_{t-1}+\varepsilon_{t}
\end{aligned}
$$

$\alpha_{1}, \alpha_{2}, \alpha_{3}, \alpha_{4}$, and $\alpha_{5}$ are short-run parameters while $\lambda_{1}, \lambda_{2}, \lambda_{3}, \lambda_{4}$ and $\lambda_{5}$ are long-run parameters. The ARDL framework allows "Bounds test" to expeditiously determine the cointegrating relation in small sample cases (Tang, 2003). This approach is suitable and flexible to any regressor order of integration, either $I(0)$ or $I(1)$ or mutually cointegrated while the dependent variable is expected to be $I(1)$. It also allows for a large number of choices such as decisions with respect to the number of endogenous and explanatory variables. The approach permits a different number of optimal lags combination for different variables as well as capturing short-run and long-run coefficients independently.

As earlier mentioned, the study employed the Pesaran et al. (2001) ARDL model for the eight countries instead of the panel approach to avoid the problem of obscuring countries' specificities. In addition, it allows for easy analytical comparison amongst the countries in terms of their performance. This modelling technique is adopted due to its advantages. First, the model reveals that after suitable augmentation of the order of the ADRL model, the OLS estimators of the short-run parameters are $\sqrt{T}$-consistent with the asymptotically singular covariance matrix. Second, the estimators of the long-run coefficients of the ARDL are very consistent. Third, valid inferences on the long-run parameters can be determined by employing the standard normal asymptotic theory. Fourth, Monte Carlo experiments provide strong evidence in support of efficiency of the approach in the time series econometric modelling.

\section{Empirical result and discussion}

The summary of descriptive statistics of all the series in the estimated models for the eight countries is presented in Table 1 below. The eight countries represent the sample drawn from the West African region based on data availability. The statistic of GDP per person employed shows that Nigeria and Senegal have relatively high average values compared to the other countries. In addition, Nigeria and Ghana have the highest volatility of GDP per person employed while Niger has the lowest. This shows a wide dispersion in the distribution pattern of GDP per person in Nigeria and Ghana. The observed pattern is not different from other African countries. For instance, the growth inclusiveness is worrisome in SSA countries as the region recorded low amongst the regions in world (Oyinlola Adedeji, 2020; Oyinlola and Adedeji, 2019; Raheem et al., 2018 amongst others). This implies that African countries need huge investment in key areas such as education to foster inclusive growth in the region. 


\begin{tabular}{|c|c|c|c|c|c|c|c|c|c|}
\hline & Benin & $\begin{array}{l}\text { Burkina } \\
\text { Faso }\end{array}$ & Gambia & Ghana & Niger & Nigeria & Senegal & Togo & $\begin{array}{l}\text { Inclusive } \\
\text { growth in }\end{array}$ \\
\hline \multicolumn{9}{|c|}{ A: GDP per person employed (constant 2011 PPP \$) } & \\
\hline Mean & 4394.47 & 3174.96 & 5404.74 & 6363.22 & 2080.03 & 13378.64 & 7260.01 & 2806.61 & \\
\hline Max & 5203.15 & 4871.83 & 5741.70 & 9113.06 & 2350.15 & 19326.66 & 8077.29 & 3193.65 & \\
\hline Min & 3782.81 & 2008.73 & 5148.75 & 4852.47 & 1884.95 & 9258.21 & 6380.32 & 2331.15 & \\
\hline $\begin{array}{l}\text { Std. } \\
\text { dev }\end{array}$ & 450.29 & 960.51 & 145.48 & 1331.31 & 133.23 & 3981.58 & 547.10 & 204.35 & 169 \\
\hline No. obs & 28 & 28 & 28 & 28 & 28 & 28 & 28 & 28 & \\
\hline \multicolumn{10}{|c|}{ B: Capital stock (US million dollars) } \\
\hline Mean & 36969.21 & 33199.05 & 4806.22 & 156211.3 & 46271.45 & 731523.5 & 68086.78 & 16328.36 & \\
\hline Max & 61224.94 & 68305.40 & 8854.85 & 317259.4 & 78982.06 & 1958762 & 114527.2 & 28342.35 & \\
\hline Min & 12351.98 & 12366.44 & 1518.51 & 79495.03 & 29780.35 & 46109.25 & 21879.26 & 10547.90 & \\
\hline $\begin{array}{l}\text { Std. } \\
\text { dev }\end{array}$ & 15907.36 & 19489.11 & 2725.23 & 88498.52 & 18737.11 & 744382.8 & 29393.83 & 6628.56 & \\
\hline No. obs & 28 & 28 & 28 & 28 & 28 & 28 & 28 & 28 & \\
\hline \multicolumn{10}{|c|}{ C: Labour force participation rate (\%) } \\
\hline Mean & 72.69 & 76.39 & 59.23 & 76.61 & 80.20 & 55.23 & 55.31 & 81.45 & \\
\hline $\operatorname{Max}$ & 73.64 & 85.09 & 60.73 & 78.12 & 80.56 & 56.40 & 59.01 & 83.80 & \\
\hline Min & 71.65 & 67.81 & 57.73 & 75.52 & 79.72 & 54.69 & 52.75 & 78.76 & \\
\hline $\begin{array}{l}\text { Std. } \\
\text { dev }\end{array}$ & 0.75 & 5.87 & 1.04 & 0.86 & 0.30 & 0.49 & 2.20 & 1.72 & \\
\hline No. obs & 28 & 28 & 28 & 28 & 28 & 28 & 28 & 28 & \\
\hline \multicolumn{10}{|c|}{ D: Primary school enrolment (\%) } \\
\hline Mean & 96.96 & 59.03 & 81.20 & 90.91 & 46.27 & 91.60 & 72.16 & 113.67 & \\
\hline $\operatorname{Max}$ & 132.47 & 93.65 & 97.12 & 108.64 & 75.10 & 102.06 & 85.85 & 127.19 & \\
\hline Min & 51.25 & 32.53 & 57.18 & 71.60 & 26.16 & 78.61 & 53.25 & 92.75 & \\
\hline $\begin{array}{l}\text { Std. } \\
\text { dev }\end{array}$ & 25.58 & 20.93 & 12.49 & 11.82 & 17.81 & 5.90 & 12.07 & 10.66 & \\
\hline No. obs & 28 & 28 & 28 & 28 & 28 & 28 & 28 & 28 & \\
\hline \multicolumn{10}{|c|}{ E: Secondary school enrolment (\%) } \\
\hline Mean & 32.25 & 16.63 & 40.49 & 45.50 & 10.80 & 33.15 & 26.21 & 38.71 & \\
\hline Max & 59.04 & 38.12 & 58.52 & 69.95 & 24.60 & 56.18 & 50.20 & 61.69 & \\
\hline Min & 20.96 & 6.89 & 17.19 & 33.95 & 6.20 & 23.11 & 14.35 & 19.99 & \\
\hline $\begin{array}{l}\text { Std. } \\
\text { dev }\end{array}$ & 14.25 & 9.51 & 18.51 & 12.73 & 5.59 & 10.16 & 0.73 & 13.90 & \\
\hline No. obs & 28 & 28 & 28 & 28 & 28 & 28 & 28 & 28 & \\
\hline \multicolumn{10}{|c|}{ F: Index of human capital development } \\
\hline Mean & 1.48 & 1.12 & 1.37 & 2.16 & 1.13 & 1.57 & 1.37 & 1.70 & \\
\hline $\operatorname{Max}$ & 1.78 & 1.24 & 1.57 & 2.39 & 1.21 & 1.88 & 1.55 & 1.78 & \\
\hline Min & 1.24 & 1.03 & 1.18 & 1.87 & 1.06 & 1.22 & 1.19 & 1.49 & \\
\hline $\begin{array}{l}\text { Std. } \\
\text { dev }\end{array}$ & 0.16 & 0.07 & 0.12 & 0.15 & 0.05 & 0.22 & 0.12 & 0.09 & \\
\hline No. obs & 28 & 28 & 28 & 28 & 28 & 28 & 28 & 28 & \\
\hline \multicolumn{10}{|c|}{ G: Foreign direct investment (\% of GDP) } \\
\hline Mean & 1.50 & 1.09 & 3.91 & 3.89 & 3.82 & 2.07 & 1.51 & 2.88 & \\
\hline Max & 6.08 & 4.10 & 12.55 & 9.52 & 16.63 & 5.79 & 2.98 & 18.82 & \\
\hline Min & -0.90 & 0.01 & -0.12 & 0.25 & -2.14 & 0.63 & -0.11 & -1.04 & \\
\hline $\begin{array}{l}\text { Std. } \\
\text { dev }\end{array}$ & 1.74 & 0.14 & 3.36 & 2.90 & 5.01 & 0.63 & 0.87 & 3.57 & \\
\hline \multirow[t]{2}{*}{ No. obs } & 28 & 28 & 28 & 28 & 28 & 28 & 28 & 28 & \\
\hline & & & & & & & \multicolumn{2}{|r|}{ (continued) } & $\begin{array}{r}\text { Table } 1 . \\
\text { Descriptive statistics }\end{array}$ \\
\hline
\end{tabular}




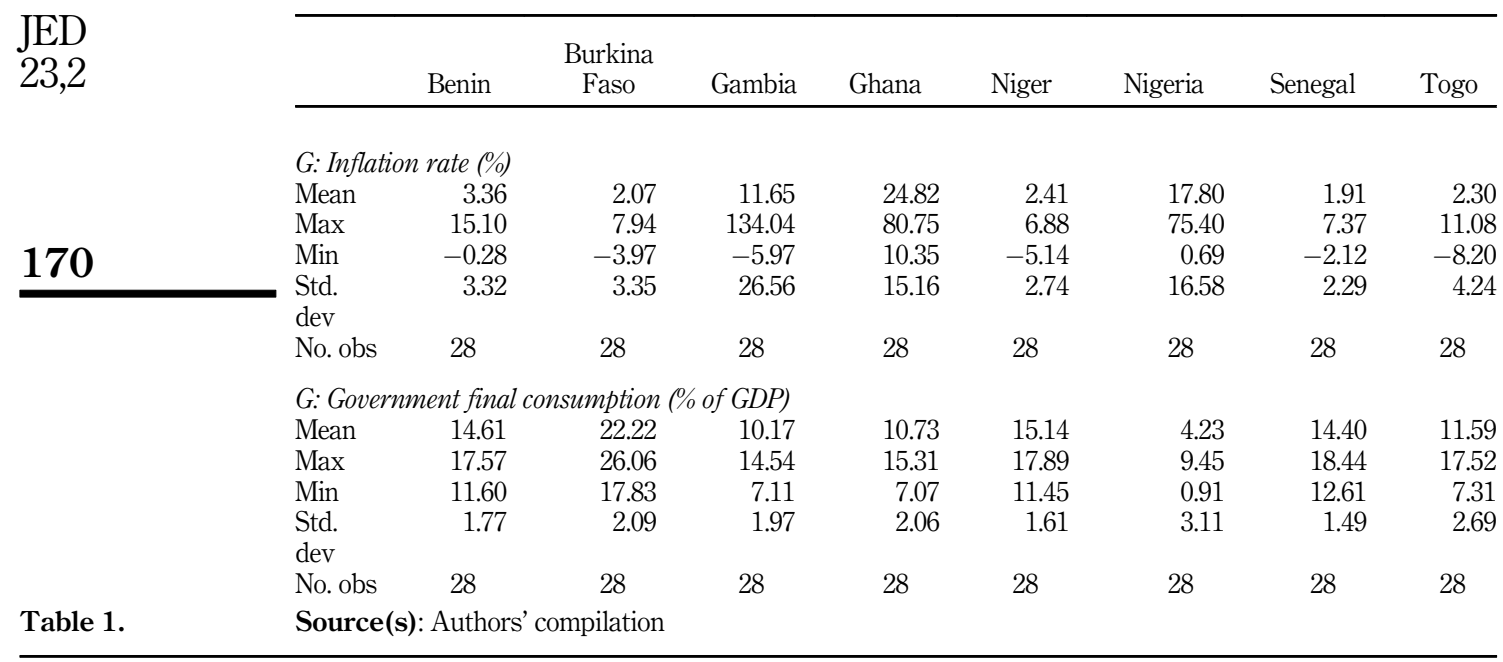

On capital stock, the statistical summary reveals that Nigeria and Ghana also have the highest average values amongst the eight countries. On the other hand, Gambia recorded the lowest value. In terms of fluctuation, Nigeria has the highest due to large dispersion as indicated by the huge difference between minimum and maximum values. On the other hand, Gambia has the lowest dispersion.

Focussing on the average value of labour force participation rate, Niger and Togo recorded the highest relative to other countries. However, Burkina Faso has the lowest standard deviation which indicates a small gap in terms of participation of potential workers in the labour market. In terms of primary school enrolment, Togo recorded the highest mean value compared to other countries. However, the average value of primary school enrolment is significantly low in Burkina Faso. In terms of standard deviation, Benin is largely unstable while Nigeria is the most stable. More so, Ghana has the highest mean value of secondary school enrolment while Burkina Faso is adjudged to record the lowest value. On the index of human capital development, Ghana has the largest while Burkina Faso recorded the lowest. In terms of standard deviation, Niger recorded the lowest value while Nigeria is the most volatile. In addition, the mean value of inflation rate is very high in Ghana relative to other countries and Niger has the least volatile. Burkina Faso has the highest average value of government final consumption. In summary, the information in Table 1 provides an insight into the pattern of growth inclusiveness and its drivers across the sample eight of West African economies.

To examine the stationarity of the series, the study uses two unit root tests, namely; ADF and Philip Perron (PP) unit root tests [4]. The two tests complement each other to establish the stationarity of the series. All the series are stationary either at level, $I(O)$ or first difference, I(1). Given one of the preconditions for the utilization of ARDL, the unit root tests contain both level and first difference series and importantly the dependent variable is also stationary at first difference. Thus, this justifies the utilization of ARDL approach to examine the short-run and long-run impacts of education in terms of quantity and quality, on inclusive growth in West Africa. Also, the result of the bounds test in Tables 2-4 show that there is long-run relationship amongst the variables in all the models across the countries.

For detailed analysis, the results are in two folds. Education is measured in terms of quantity and quality. Different proxies are utilised to capture the role of education. Table 2 


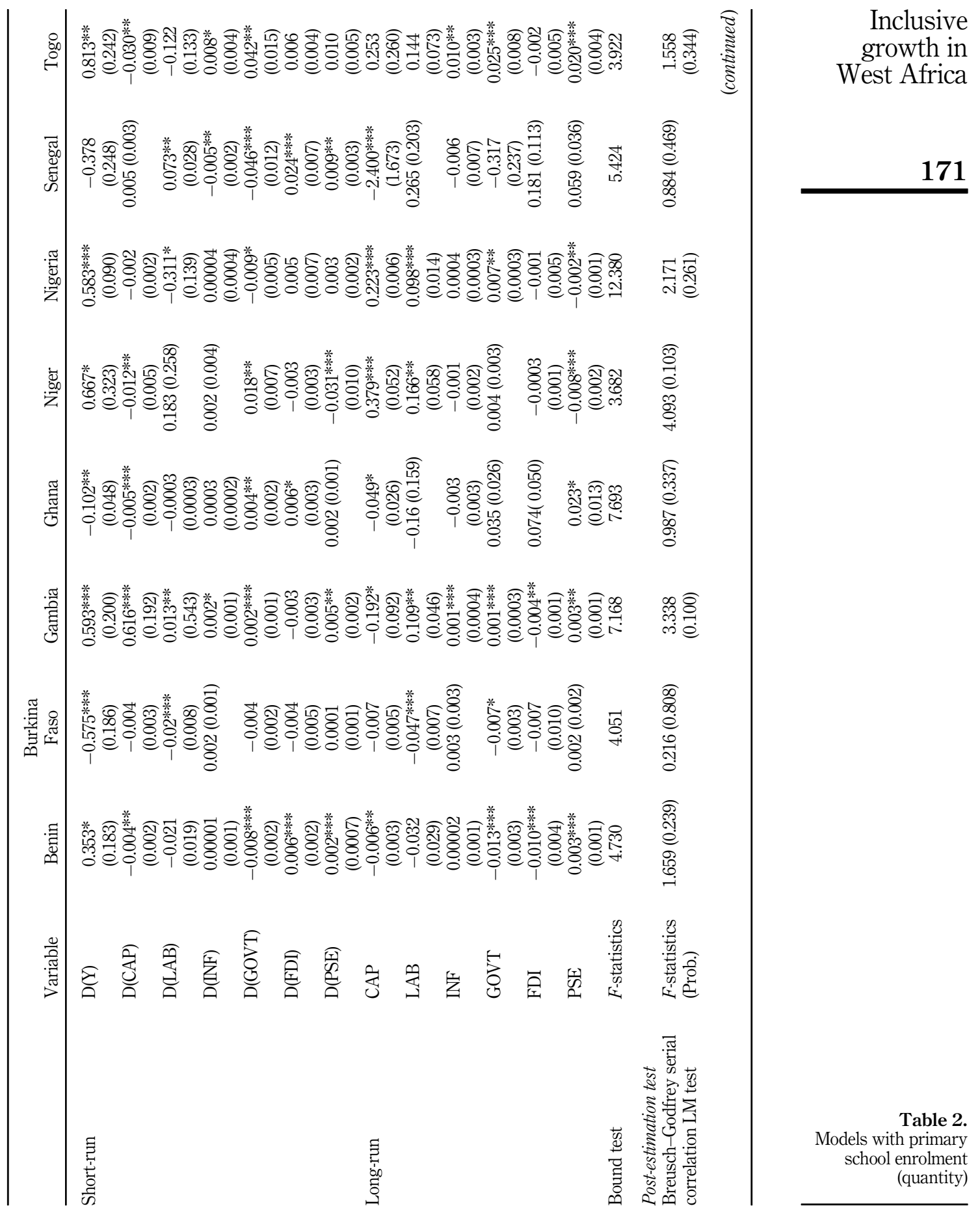


JED
23,2

172

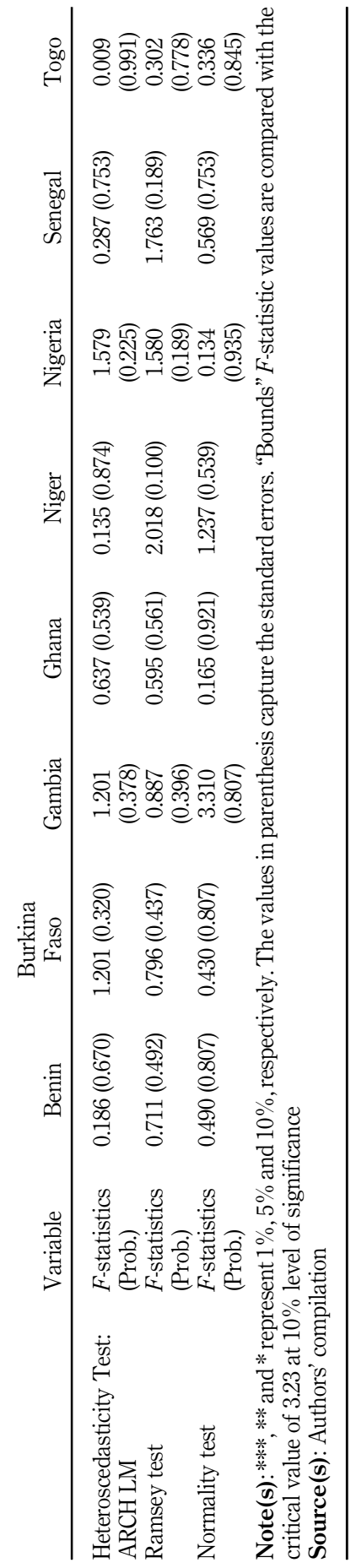

Table 2. 


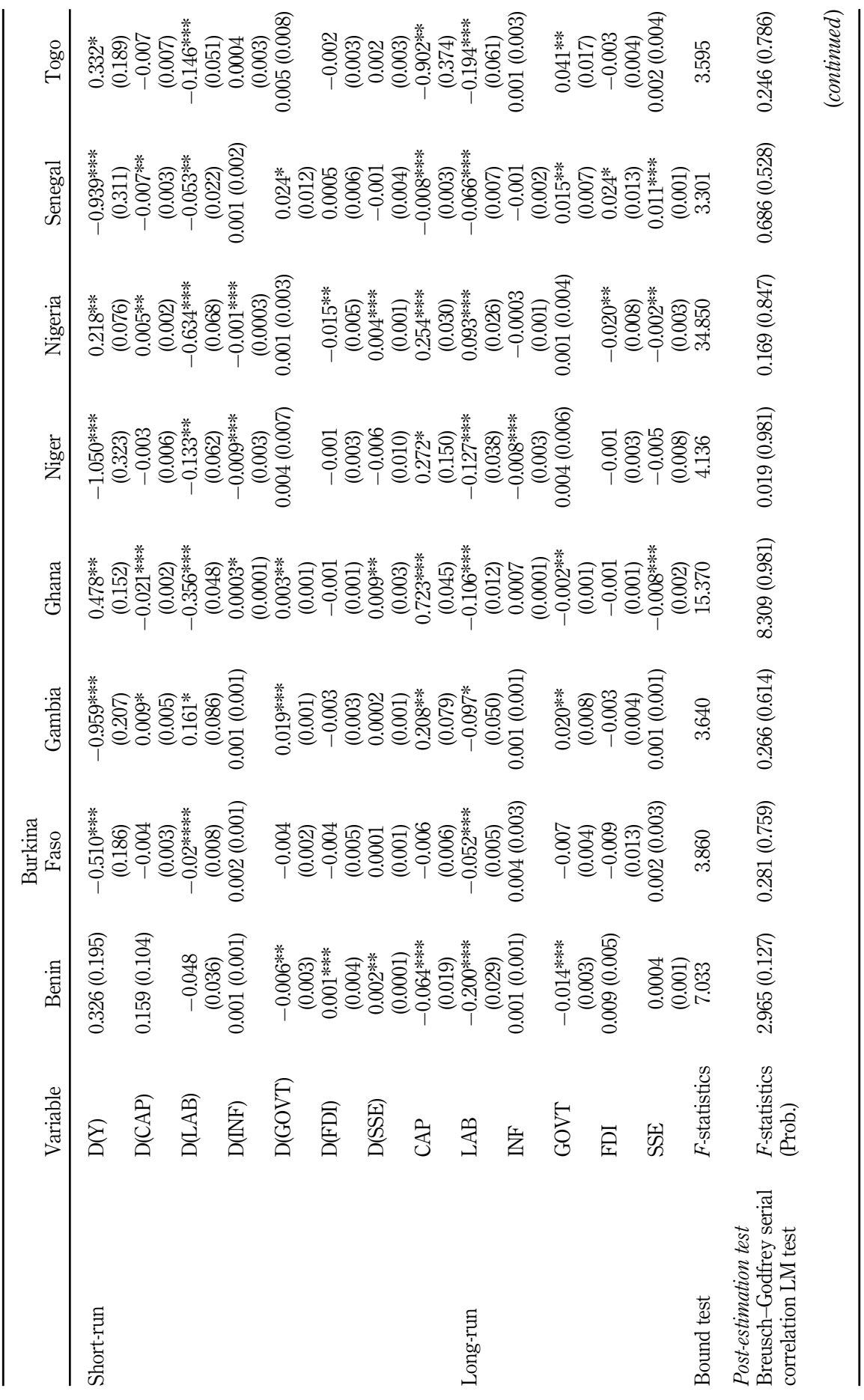

Inclusive
growth in
West Africa

173

Table 3.

Models with secondary school enrolment (quantity) 
JED
23,2

174

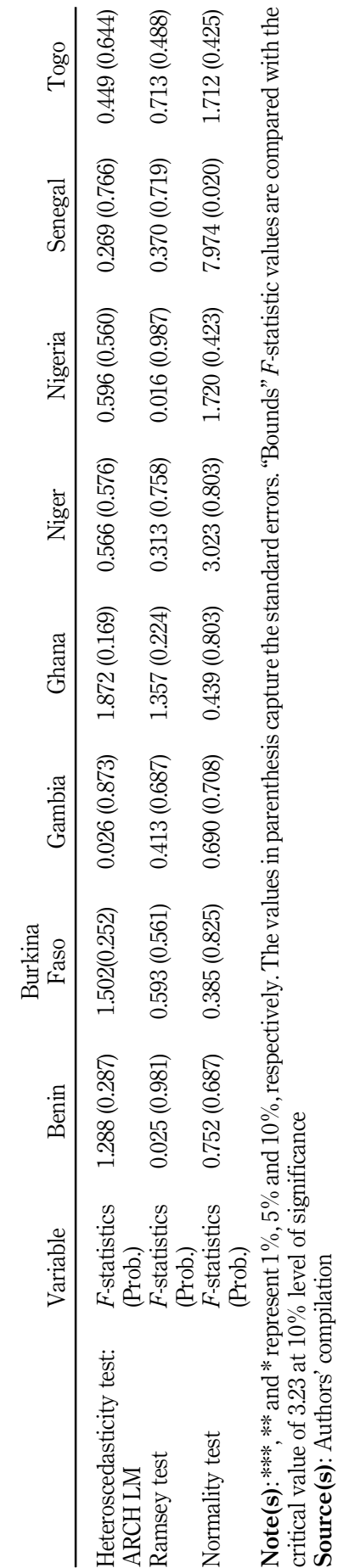

Table 3. 

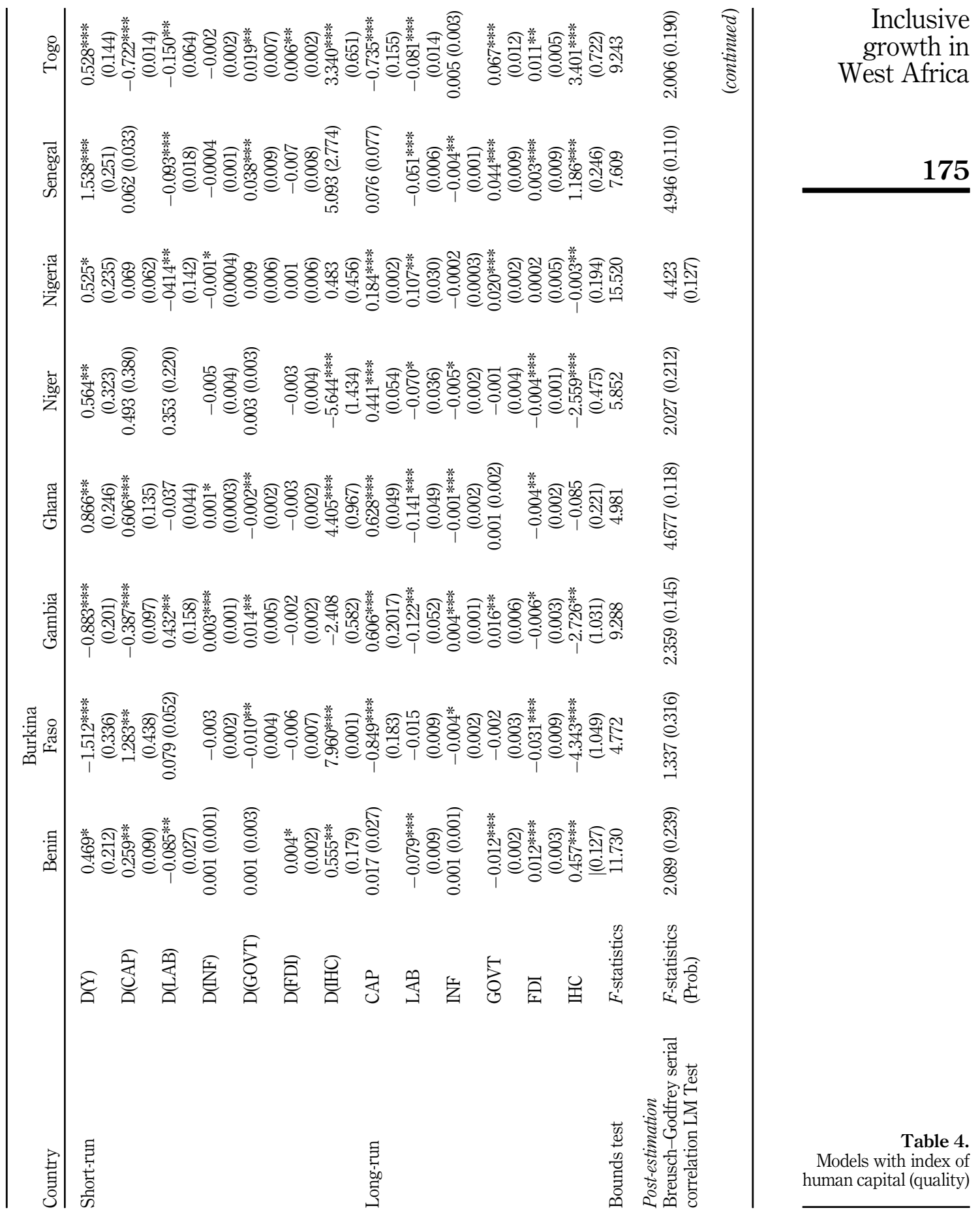
JED
23,2

丞

尽

芯

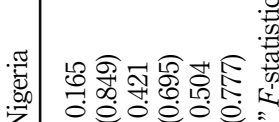

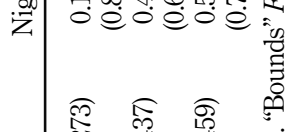

范

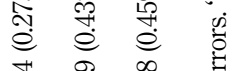

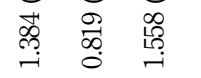

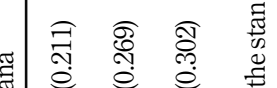

్ㅟㄴ

节 学

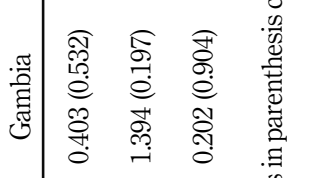

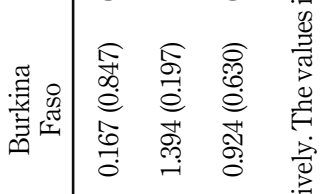

慁空

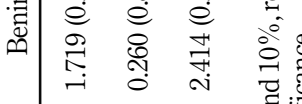

कु भु

曾

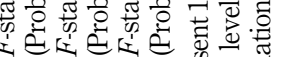

स्स

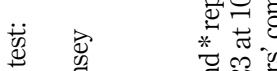

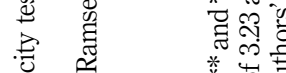

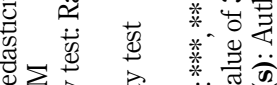

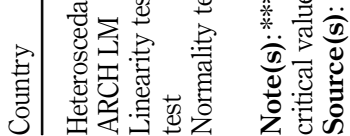

Table 4. 
presents the empirical results from ARDL estimation with primary school enrolment across the eight countries in the region. The results reveal that the initial level of inclusive growth plays a significant role in determining the current level of inclusiveness. The coefficients of lagged dependent variables are positive and statistically significant in five countries (Benin, Gambia, Niger, Nigeria and Togo) while negative but only statistically significant in two countries, namely, Ghana and Burkina Faso. Togo recorded the highest impact as indicated by the large coefficient. Thus, the extent to which people benefit from economic prosperity depends on production expansion and participation in the production process in the previous year. The short-run coefficients of capital stock are largely negative (Benin, Burkina Faso, Ghana, Niger, Nigeria and Togo). However, the short-run coefficient of capital stock is positive and statistically significant. This implies that capital stock exerts a negative impact on inclusive growth in most of the countries in the region. The plausible reason may be attributed to the paucity of capital stock necessary to expand productivity which supposed to create opportunities for the teeming population in these countries.

Further, the short-run coefficient of labour is negative across the countries except in Gambia, Niger and Senegal. This suggests that labour serves as a drag on the growth inclusiveness in most of these countries. Exceptionally, labour exerts a positive impact on inclusive growth in Gambia and Senegal. This may be linked to the participation of a large proportion of the labour force in these countries. Also, the short-run coefficient of inflation is positive in all the models across the countries except in Senegal. This implies that inflation does not exert significant influence on the growth inclusiveness in all these countries. On government spending, the results are mixed across the countries. The coefficients are negative for four countries (Benin, Burkina Faso, Nigeria and Senegal) while positive for the other four countries (Gambia, Ghana, Niger and Togo) but statistically significant in seven models except for Burkina Faso. The government spending can promote inclusive growth as indicated by positive influence in the four countries. In all, the coefficients are significantly small across the countries. Also, the results of FDI are mixed across the countries. The shortrun coefficient of FDI is very small except for Senegal. Four countries recorded positive impacts while the other four recorded negative impacts. Economically, these results provide insight into the nature of foreign investment inflows which appear not to create many opportunities for the people to participate in the growth process. This finding is similar to the robust studies by Iwasaki and Suganuma (2015) and Oyinlola and Adedeji (2020).

Focussing on educational quantity, primary school enrolment, the estimated short-run elasticities are positive across the countries except for Niger. In terms of statistical significance, they are only significant in four countries. Economically, the elasticities are very small across the countries. For instance, a 100\% increase in primary school enrolment leads $0.2 \%, 0.5 \%$ and $0.9 \%$ in inclusive growth for Benin, Gambia and Senegal, respectively. Overall, the results imply that primary school enrolment exerts low influence on growth inclusiveness in all these countries. It further suggests that acquiring primary education may not suffice for people to participate in lucrative production process. Given world dynamics in development, enroling in primary school may serve as a precondition for building human capacity, but relying on this alone may not sufficiently equip the teeming population with required skills and knowledge to drive the economy on a sustainable growth path.

The next discussions focus on the long-run impact of primary school enrolment on inclusive growth across the countries. Starting with capital stock, its estimated coefficients changed significantly in terms of signs and level of significance for some of the countries. For the Gambia, its estimated coefficient changes to negative while the coefficient for Niger changes to positive. The estimated coefficient for Nigeria remains positive and statistically significant. This suggests that countries such as Nigeria and Niger experienced improvement in the inclusive growth through capital accumulation. In the growth literature, capital stock is expected to exert a positive impact on the long run growth. Thus, the capital stock has the
Inclusive growth in West Africa 
JED

23,2

potential to expand the production process in the long run for many people to be absorbed thereby making growth inclusive. In addition, the paucity of capital in countries such as Benin, Burkina Faso and Ghana, dampened growth inclusiveness.

Further, the long-run coefficients of labour are positive for five countries but only statistically significant in four countries. This tends to imply that labour spurs growth inclusiveness in the long run in some of these countries. This may suggest that the bourgeoning labour force has the tendency for promoting growth inclusiveness in the longrun if there is improvement in human capacity development across these countries. On inflation, the estimated long-run coefficients are not significantly different from the pattern observed in the short-run. In addition, the coefficients remain inconsequential. On government spending, the coefficients are significantly small with slight changes in the signs and level of significance. The long-run impact of foreign direct investment is not significantly different from its short-run impact.

The long-run impact of primary school enrolment on the inclusive growth across the countries is largely dominated by the positive signs. Though, its magnitudes remain very small in the long run. Thus, the fact remains that primary school enrolment may not be enough to drive robust growth inclusiveness. Despite the increase in primary school enrolment in these countries, the unemployment level remains at an alarming rate. This further suggests that growth inclusiveness may be dampened when a large proportion of the population possess only primary education qualification. In reality, many people with this education qualification do the menial job which may significantly hinder growth inclusiveness. R\&D, invention, innovation and discoveries require high-quality skills and knowledge which primary education is not designed to provide.

The subsequent discussion focuses on the influence of secondary school enrolment on inclusive growth in the region as presented in Table 3. Focusing on the short-run estimates, there is a significant difference in terms of magnitudes, direction and level of significance, in the impact of the lagged dependent variable in this case. The coefficients of the lagged dependent variable are positive and statistically significant only in three countries (Ghana, Nigeria and Togo) while negative but only statistically significant in four countries (Burkina Faso, Gambia, Niger and Senegal). Ghana recorded the highest positive impact as indicated by a large coefficient while Niger recorded the highest negative impact across the models. Thus, for countries that recorded positive impact, this suggests that the extent to which people benefit from economic prosperity by participating in the production process in the previous year plays a significant role in determining growth inclusiveness in these countries.

On the other hand, in the countries that recorded a negative impact, the previous year's inclusive growth dampened the current level of inclusive growth. Further, there is a change in capital stock with respect to signs and level of significance in five countries when compared with the result in Table 2 . The results remain mixed when secondary school enrolment was introduced. On labour, the results are largely negative and statistically significant for all countries except for Benin. This is indicative of the drag effect of labour on inclusive growth. In addition, there is a slight deviation of results on inflation and government spending from earlier results in Table 4. On foreign direct investment, the results show predominantly positive impacts but the magnitudes remain trivial.

Further, the second part of the discussion focuses on the role of secondary school enrolment in the growth inclusiveness process across countries in the region. The results show largely positive impacts of the secondary school enrolment on inclusive growth. Undoubtedly, secondary education is very important to growth inclusiveness in the region. Improvement in this level of education provides individuals with requisite skills to actively participate in the growth process. However, despite the positive impact, the magnitudes remain very low. For instance, a $100 \%$ increase in the secondary school enrolment leads to $0.2,0.9$ and $0.4 \%$ in inclusive growth for Benin, Ghana and Nigeria, respectively. Focusing on the long-run results, 
the traditional determinants yield results similar to those reported in Table 2. Although, there are slight changes in the magnitude and direction of the coefficients. For instance, the direction of capital stock changes for Gambia, Ghana and Togo. However, labour is largely negative and statistically significant when compared to the results in Table 2. Inflation is still dominated by positive coefficients across the countries and a similar pattern is observed in government expenditure. However, foreign direct investment is largely negative with more than half of the models statistically insignificant. The results show that secondary school enrolment is largely positive but only statistically significant in three models. This is an indication that secondary school education has potential to amplify the inclusive growth in these countries. These findings further support the argument of Nowak and Dahal (2016) that higher education enhances growth process faster than primary education.

The last part of the discussion focuses on the results when the education quality is introduced in terms of the index of human capital (computed from the average years of school and rate of return on education). Shifting attention to Table 4, the short-run results show that the lagged dependent variable is largely positive and statistically significant in all the models. The short-run coefficients of capital stock are largely positive compared to when education quantity was introduced. In the presence of quality education, capital plays a more significant role in driving the growth inclusiveness of most of the countries. Judging by the volume of capital stock, Gambia and Togo have the least amongst the countries. The low capital stock in these countries may be the major reason why it appears to be dampening inclusive growth. The narrative on labour does not significantly change as it is dominated by the negative signs. A plausible reason may be attributed to the predominance of underemployment and low skilled labour in most of these countries.

Expectedly, inflation is largely dominated by negative signs across the countries contrary to the finding under the earlier two measures of education quantity. Thus, inflation always exerts a negative impact on inclusive growth in these countries. Also, a similar pattern is observed for government spending. Foreign direct investment continues to drive non-inclusiveness of growth as its benefit accrues to a small portion of the population in the region. Focusing on the education quality as measured by the index of human capital, the results mostly reveal a positive influence of education quality on inclusive growth across the board. Quality education goes a long way in providing the individual with high-skills to drive $R \& D$, innovation, discoveries and invention which are critical to inclusive growth. In addition, productive labour (with quality education) benefits from economic prosperity arising from the attendant growth. As productivity continues to expand, the gains from growth that accrue to an individual may depend to a larger extent, on the quality of skills acquired through education.

The long-run results of the traditional determinants slightly deviate from what we observed in Tables 2 and 3. The capital stock continues to exert a positive impact on inclusive growth in most of the countries while labour is largely negative across the countries. In addition, inflation is largely negative and statistically significant. Government spending is dominated by positive impact across the countries while foreign direct investment has both positive and negative impacts across the countries. Strikingly, education quality exerts a negative impact on the inclusiveness of growth in most of the countries except Benin, Senegal and Togo. We can interpret this to suggest that inclusive growth was not broadly enhanced by the education quality. The region is dominated by unskilled labour which may be a plausible reason for this outcome. In addition, the region is characterised by high out-ofschool children which has the implication for the growth inclusiveness since they are likely to be constrained by lack of skills to participate in the growth process in the long run. One can therefore conclude, by and large, that models with education quality perform better than the models with education quantity. Thus, education quality matters more for growth inclusiveness in the West Africa region. The post-estimation tests as presented in the tables show that the models are free from the problem of heteroscedasticity, serial
Inclusive growth in West Africa 
JED

23,2

autocorrelation, non-normality and non-linearity. Thus, the inferences drawn from the results are valid. Interestingly, this finding projects the low-quality education that characterised most countries in Africa (Wolfenden, 2015). This complicates the zeal of moving towards growth inclusiveness amongst the countries in the West African region.

\section{Conclusion and policy suggestions}

Using the ARDL modelling approach with annual time series data from 1990 to 2017, the study examined the impact of education (quantity and quality) on growth inclusiveness in eight countries in West Africa. The findings from the estimated models showed that the initial level of growth inclusiveness played a significant role in the determination of inclusive growth across the countries. The findings in the short run further showed that education quantity (primary school enrolment) exerted a positive impact on inclusive growth to a large extent. However, this impact was significantly small across countries. A similar impact is observed in the long run. The short-run results also indicated that education quality (secondary school enrolment) positively influenced inclusive growth in most of the countries in the region but with inconsequential magnitudes. In the long-run, a positive impact was also observed in more than half of the countries. For countries such as Ghana, Niger and Nigeria, education quantity dampened their growth inclusiveness. In addition, the short-run results revealed that education quality played a significant role in enhancing inclusive growth. However, this pattern is not totally sustained in the long-run as only three countries (Benin, Senegal and Togo) recorded positive impacts. Overall, the narrative is pointing to the fact that education quality is very important in spurring growth inclusiveness in the region. The inability of these West African countries to address educational issues may hinder the achievement of inclusive growth. This will further exacerbate the socio-economic problems such as unemployment, poverty, inequality amongst others. Drawing from the foregoing findings, the policymakers can truly foster growth inclusiveness within these countries as well as in the entire region by focussing on the following: (1) Designing education policy that will offer opportunities for easy access to the education by teeming population: there is need for these countries to make education free and mandatory by law at least at primary and secondary levels since the level of poverty is alarming. Despite that, most countries have initiate this at primary, there is need for enforcement and extension to other levels of education due to low income of most households in the region; (2) Quality teachers: there is a need for effective policy that will ensure regular and high quality training of educators as well as raising the standard of the profession. The potential to improve teachers' status at all levels of education to foster professional development practice is very important for these countries. This is essential for quality workforce that are needed for growth inclusiveness; (3) Upgrading school infrastructure to promote the quality of education should be a focal point for all governments that aim to deliver quality education to their citizenry and thereby serving as a catalyst for achieving inclusive growth; (4) Institutional structures central to the educational system needs to be overhauled to create conducive environment for learning and skills acquisition. The study is limited to West African countries. Thus, there is a need for future studies to explore this assertion in other African sub-regions.

\section{Notes}

1. Alfaro et al. (2001) and Iwasaki and Suganuma (2015)

2. Khan and Senhadji (2000)

3. Arpaia and Turrini (2008)

4. Due to space constraint, the results are available on request. 


\section{References}

Adedeji, A. and Adeniyi, O. (2019), Remittances, Human Capital and Inclusive Development in the ECOWAS Region, available at: http://www.crepol.org/articles/remittances-human-capital-andinclusive-development-in-the-ecowas-region.

Alfaro, L., Chanda, A., Kalemil-Ozcan, S. and Sayek, S. (2001), "Does foreign direct investment promote economic growth? Exploring the role of financial markets on linkages", Journal of Development Economics, Vol. 91 No. 2, pp. 242-256.

Ali, I. and Son, H. (2007), "Defining and measuring inclusive growth: application to the Philippines", ERD Working Paper Series No. 98, Asian Development Bank, Metro Manila.

Arezki, R. and Nabli, M.K. (2012), "Natural resources, volatility, and inclusive growth: perspectives from the Middle East and North Africa”, OxCarre Working Paper 086, Oxford Centre for the Analysis of Resource Rich Economies, University of Oxford.

Arpaia, A. and Turrini, A. (2008), Government Expenditure and Economic Growth in the EU: Long-Run Tendencies and Short-Term Adjustment, European Economy Economic Papers No. 300, Directorate General Economic and Financial Affairs (DG ECFIN), European Commission, Brussels.

Ayinde, T.O. and Yinusa, O.G. (2016), "Financial development and inclusive growth in Nigeria: a threshold analysis", Acta Univ Danubius, Vol. 12 No. 5, pp. 166-189.

Babatunde, M.A. and Adefabi, R.A. (2005), "Long-Run relationship between education and economic growth in Nigeria: evidence from the Johansen's cointegration approach", Paper presented at the Regional Conference on Education in West Africa: Constraints and Opportunities Dakar, Senegal, November 1st - 2nd, 2005.

Barro, R.J. (2013), "Education and economic growth", Annals of Economics and Finance, Vol. 14 No. 2A, pp. 277-304.

Barro, R.J. and Lee, J. (2013), "A new data set of educational attainment in the world, 1950-2010", Journal of Development Economics, Vol. 104, pp. 184-198.

Becker, B. and Hall, S.G. (2013), "Do R\&D strategies in high-tech sectors differ from those in low-tech sectors? An alternative approach to testing the pooling assumption", Economic Change and Restructing, Vol. 46, pp. 183-202.

Cohen, D. and Leker, L. (2014), Health and Education: Another Look with the Proper Data mimeo, Paris School of Economics, Paris.

Delgado, M.S., Henderson, D.J. and Parmeter, C. (2013), "Does education matter for economic growth?", Oxford Bulletin of Economics and Statistics, Vol. 76 No. 3, pp. 334-359.

Gyimah-Brempong, K., Paddison, O. and Mitiku, W. (2006), "Higher education and economic growth in Africa", Journal of Development Studies, Vol. 42 No. 3, pp. 509-529.

Hanushek, E.A. and Wößmann, L. (2007), "The Role of Education Quality in Economic Growth", World Bank Policy Research Working Paper 4122, The Work Bank, Washington, DC.

Ianchovichina, E. and Gable, S.L. (2012), "What is inclusive growth?", in Arezki, R., Pattillo, C., Quintyn, M. and Zhu, M. (Eds), Commodity Prices and Inclusive Growth in Low-Income Countries, International Monetary Fund, Washington, DC.

Iwasaki, I. and Suganuma, K. (2015), "Foreign direct investment and regional economic development in Russia: an econometric assessment", Economic Change and Restructuring, Vol. 48, pp. 209-255, doi: 10.1007/s10644-015-9161-y.

Jalil, A. and Idrees, M. (2013), "Modeling the impact of education on the economic growth: evidence from aggregated and disaggregated time series data of Pakistan", Economic Modelling, Vol. 31, pp. 383-388.

Khan, M.S. and Senhadji, A.S. (2000), "Threshold Effects in the Relationship between Inflation and Growth", IMF working paper. WP/00/110, International Monetary Fund, Washington, DC.

Inclusive growth in West Africa 
JED

23,2

182

Kotásková, S.K., Procházka, P., Smutka, L., Maitah, M., Kuzmenko, E., Kopecká, M. and Hönig, V. (2018), "The impact of education on economic growth: the case of India", Acta Universitatis Agriculturae et Silviculturae Mendelianae Brunensis, Vol. 66 No. 1, pp. 0253-0262.

Lin, T.C. (2003), "Education, technical progress, and economic growth: the case of Taiwan", Economics of Education Review, Vol. 22, pp. 213-220.

Lin, J.Y. (2012), The Quest for Prosperity: How Developing Economies Can Take off, Princeton University Press, Princeton, NJ.

Mankiw, N.G., Romer, D. and Weil, D. (1992), “A Contribution to the empirics of economic growth”, Quarterly Journal of Economics, Vol. 107 No. 2, pp. 407-438.

Nowak, A.Z. and Dahal, G. (2016), "The contribution of education to economic growth: evidence from Nepal”, International Journal of Economic Sciences, Vol. 5 No. 2, pp. 22-41.

OECD (2013), Speech by OECD Secretary General Angel Gurria, at OECD Workshop on Inclusive Growth, Together We Stand: Inclusive Growth, Organisation for Economic Cooperation and Development, Paris, 3 Apr 2013.

Oyinlola, M.A. and Adedeji, A. (2019), "Human capital, financial sector development and Inclusive growth in sub-Saharan Africa”, Economic Change and Restructuring, Vol. 52 No. 1, pp. 43-66.

Oyinlola, M.A. and Adedeji, A.A. (2020), "Enhancing economic growth impact of financial Development and human capital through capital Flows in sub-Saharan Africa”, Journal of Economic Development, Vol. 45 No. 2, pp. 95-114.

Pastor, J.M., Peraita, C., Serrano, L. and Soler, L. (2018), "Higher education institutions, economic growth and GDP per capita in European Union countries", European Planning Studies, Vol. 26 No. 8, pp. 1616-1637.

Psacharopoulos, G. (1994), "Returns to investment in education: a global update", World Development, Vol. 22 No. 9, pp. 1325-1343.

Pesaran, M.H., Shin, Y. and Smith, R.J. (2001), "Bounds testing approaches to the analysis of level relationships", Journal of Applied Econometrics, Vol. 16, pp. 289-326.

Raheem, I.D., Kazeem, O.I. and Adedeji, A.A. (2018), "Inclusive growth, human capital development and natural resource rent in SSA", Economic Change and Restructuring, Vol. 51, pp. 29-48.

Saad-Filho, A. (2010), "Growth, poverty and inequality: from Washington consensus to inclusive growth", Working Papers 100, United Nations, Department of Economics and Social Affairs.

Sacerdoti, E., Brunschwig, S. and Tang, J. (1998), "The Impact of Human Capital on Growth: Evidence from West Africa”, IMF Working Paper. WP/98/162, International Monetary Fund, Washington, DC.

Tang, T.C. (2003), "Japanese aggregate import demand function: reassessment from 'bound' testing approach", Japan and the World Economy, Vol. 15 No. 4, pp. 419-436.

Warner, A. (2012), "Inclusive growth in natural resource intensive countries", in Arezki, R., Pattillo, C., Quintyn, M. and Zhu, M. (Eds), Commodity Prices and Inclusive Growth in Low-Income Countries, International Monetary Fund, Washington, DC.

WDI (2016), World Development Indicators, World Bank Group, available at: http://data.worldbank. org/data-catalog/world-development-indicators.

Wolfenden, F. (2015), Why Africa Needs New Solutions to its Education Challenges, available at: https:// www.weforum.org/agenda/2015/06/why-africa-needs-new-solutions-to-its-education-challenges/.

World Development Indicators (2018), World development indicators dataset, World Bank Group, available at: http://data.worldbank.org/data-catalog/world-development-indicators (accessed 20 July 2019).

World Economic Forum (2014), World Economic Forum on Africa: Forging Inclusive Growth and Creating Jobs, World Economic Forum, Geneva. 


\section{Further reading}

Bannerjee, A., Dolado, J.J., Galbraith, J.W. and Hendry, D.F. (1993), Co-integration, Error Correction, and the Econometric Analysis of Non-stationary Data, Oxford University Press, Oxford.

Cohen, D. and Marcelo, S. (2007), "Growth and human capital: good data, good results", Journal of Economic Growth, Vol. 12 No. 1, pp. 51-76.

Granger, C.W.J. and Newbold, P. (1974), "Spurious regression in econometrics", Journal of Econometrics, Vol. 2, pp. 111-120.

Lau, L.J., Damison, D.T., Liu, S.C. and Rivkin, S. (1993), "Education and economic growth: some crosssectional evidence from Brazil”, Journal of Development Economics, Vol. 41, pp. 45-70.

Shrestha, M.B. and Chowdhury, K. (2005), "ARDL Modelling Approach to Testing the Financial Liberalization Hypothesis", Economics Working Paper Series 2005 (WP 05-15), University of Wollongong, June, available at: http://www.uow.edu.au/commerce/econ/wpapers.html (accessed 20 June 11).

\section{Corresponding author}

Abdulfatai Adekunle Adedeji can be contacted at: adedejiabdulfatai@gmail.com
Inclusive growth in West Africa

For instructions on how to order reprints of this article, please visit our website: www.emeraldgrouppublishing.com/licensing/reprints.htm Or contact us for further details: permissions@emeraldinsight.com 